ナ織い翌のにナなツ货権を会た与

于さす年こ同チ社のつを挙学。え一 ズれるーと調ス会社し獲げかそら九 么て服月唯に的の学会と得たられれ、

りると大会公代を者般たと华亚を年 -

䏠忠学学ンに網は船後は社行の

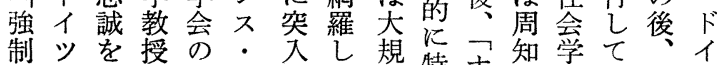

的社確の活フして模特

同会約身動ラた、势徽チ事と会イで

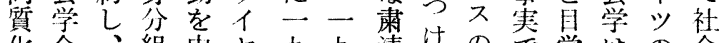

化会、組中ヤ九九清けので覚はの会

議さ織止 1 至 0 の強あま独主学

にもらです志劣対れ制るし立要は

屈之にある壳年年象る的。い科な大

服れ社る誘豆九にと十同し理学大学

しに会ド因創なチ質か論と学の

、同学イに西に設つス化し展しに講

追調プツな岕そさたの立開て社座

随す口大っ今のれ。文非九を市会と

寸るパ学たを学たと化政至遂民学乞

るよ1連と新会ドく政治三げ権のて

ようの盟いたのイに策的年、を講の

うに教がわに会商、に的に着獲座位

にな授七れ選長社ドよなナ奏得が置

なり、教うま出に会イさ自手な゙研、新を

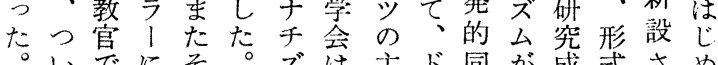

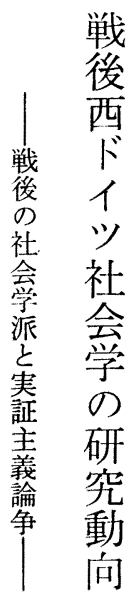

いでにそ。ズは主ド同が成式さめ

に組たのこム、要イ質政果社れて

再も月 デ編策内に防自にイか

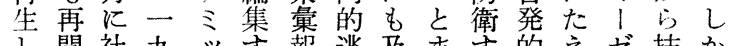

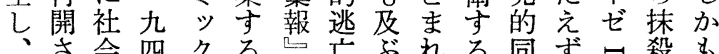

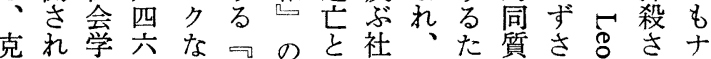

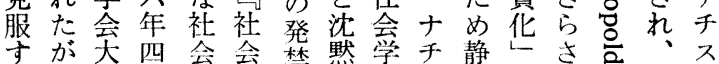

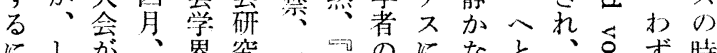

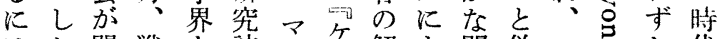

はか開戦を誌㕚解よ闒偽恐をか代

乙催後め起准る争装怖引のに

さナさはぐのス社と济しと离良は

ら千れじる国? 社免イ続な相の心り

にスため状外六拿職兴访が互の的べ

十の。て況でル学社てら畐をなら

数時同ドののク四国会い、不と大ル

年代時イ一刊八季赫学た大否で学な

間ににツ側行众報への学信、教社

をお、社面がマのの肃に慆ナ官会

要け大会でナ|廃亡清拉禾方学

しる学学あチ廃命年汀さスレは

た社で会っスる刊と弾る㞦の才研

と会社はたの㸚司逃社つ監ポ究

い学会再照社亡会会拿? 視ル

れ死のさ比含科国佒のつス! 議

て滅研机究学内の専非パフの

111

本

鎮

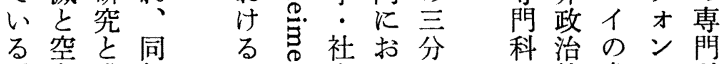

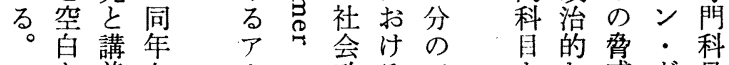

を義九力の政る二をな威ヴ目 
るてそいいしちオ㔯、見フ伝科継方ムヴをイ 狆るかかな二空、さルこ統学承法、明兴戦

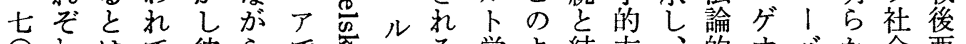
○れて彼らで芯ネる学よ結方、的才バか会西 年のいい等もあ派 方合法か遺ル!、学ド

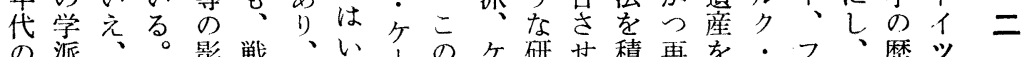
の派、。影戦、い、匇研せ積再を・フ、歴产 始のこも響後彼ずニ三ル究る極生、ジエそ史社 め拘のつ男西等れッうン傾こ的导ナンルれ会 に束三ととドがもとの学向とにるチメデら成学 はからも規イそ西、学派はで吸こズルイを果の らの三制ツれドさ派、戦も収と允の十結、必 そ自学う方社ぞイさらのシ後あしでをよン合ナ要

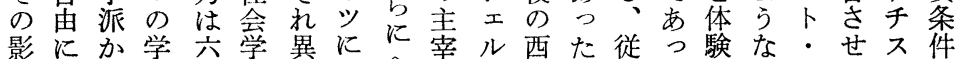

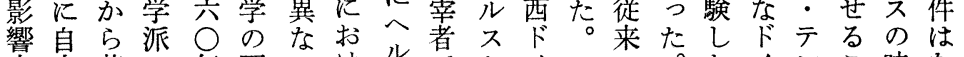
力立若の年再っけルでキイの。たインこ時な

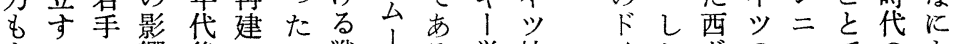
もるの響後にモ戦、る学社イが゙のエでのよ は傾社力半指于後卜ホ派会ツ壬イ偉ンあ教り や向会はに導 1 社シルの学社アツ大スっ訓も

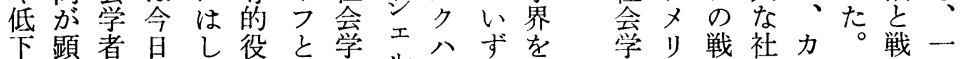
し著がでだ割理のルイ代代のカ後会|つ後九 たに成もいを論第スマに表哲での学ルまの主 とな長なに果的一キ|も专学発状者ルり社至

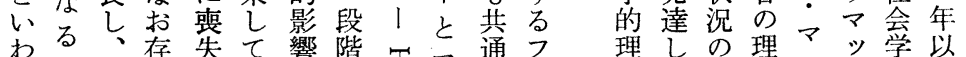
れにし続しい咅皆焉ア通ラ論たな論ンク的前 てっかしたたを兮ドてン的経か的八ス問の いれもてを。な験で・イ・題ド

会社後は翻ケ学知俗年なをテを卆!ヴ拿けイ ル学会の方訳 | 中的的しるお技六ゼイこざ理るツケ ネに学西○しムに生なの大こシ表三と、の主こ。ル ・括者年かの、産工編部なヨし年とゼ学な義としン ケ汗とイ代つ四フをッ集のうン蛙分的にて学

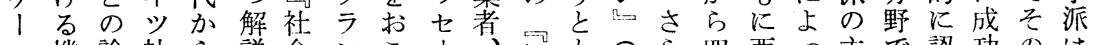
二機論社ら説会ンご、罠とつ四西っ主で認功のは \%能争会四し学、 なに著験もに作ドて等多識し研了 に主当学

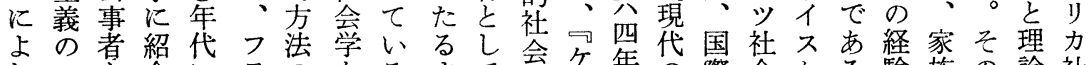

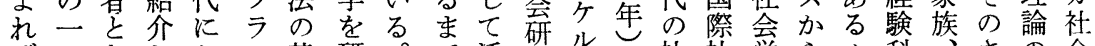
ばつなしかン基研。で活究ンル社社学らル科さの会 のるたけス準究ま、躍齐社な会会のケネ学地い量学

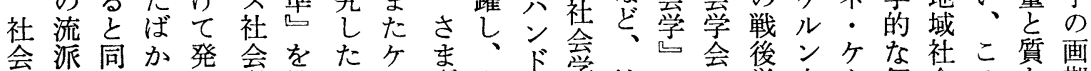

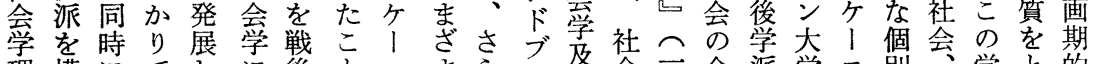
理構にでしに後々二まらッ念会九会派学二別学々的

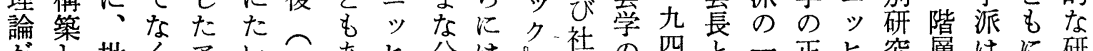

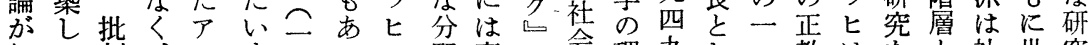

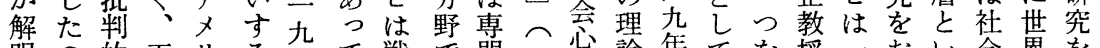
明の的五リる六て戦で䣙二岕論年てを授一沶い会界を すでな○另理—、前た的九理的、戦創と九こっ学的吸 るあ解年経解年エのぐな六学分勾後設し四なたを水収

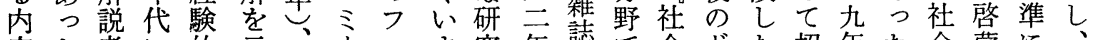
容た者に的示、门ラま究年誌で会ドた招年た会蒙に

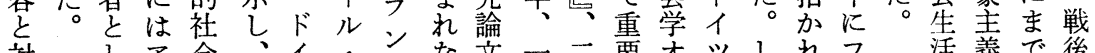
対しア会、イ・ン交一三要才ツしれフ 活義で後 象て、学さツデスほか九巻なリ社か、オ的結の は、リをら語ュにどら六よ貢エ会もヴン のが゙西 社力戦ににル留の通九り献ン学ーィ・さつつド 


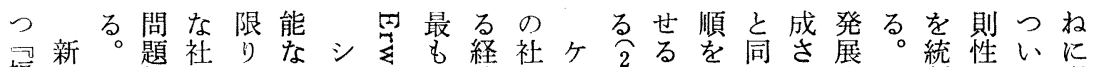
福左領会限限ヨ志上験会ル过たじれ等し制のて限

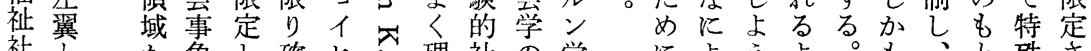

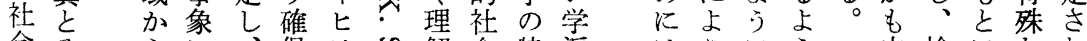
会々らに、保 のの社か㨁し経宁し研殊か 再ド会ん接よ験壳て究なら 洗グ哲す検う的气い会能若

礼、学る証と社でる方力手 派に の理哿し会あと法との 3 問論能、研 るい文社 い題的なし究す抏之の全 のて 領思もかに睤の限学 なの域考のもおお方界者 か批へををそい法をが

で判と個認のてるに明登

的追別識理方

シ研放科の論法

$\exists$ 究桴対的論

$1 飞 \tau$ 象内的

七い、しと容な

はう闭てすの信

新サ者のる射頼

左ブを経。程性

翼夕悠験だ距と

の 密的か離妥

社卜に社らを当

会ル 区表総可性

象主导の的な叮

のとら場

がもかし

エなにて

ルらしい

ヴ理、る

は、に只さ中検になれ

構重仮なり囲さ攝明自

造視説るこのれしを然 的しを。の理反よなに 機、構経よ論証うし ほ 的り寺科な徐れ試さな 説巨る学論々るみまら 明大こ的理に多るざず 原な之な的、様のま、 理理で社総よなでなそ が論め会合り諸あ抽こ 重にり学は巨命る象で 要関、研一大題。的社 さ説で社理な会べ学 論かが、割せのは会論か学ルは ン的つ、をて操、学へで理に個 的直之演命作他の之原論存々

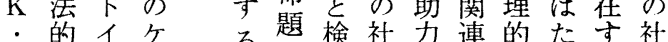
シなツルをを証会をしに会 ヨ問にンの発す諸えな運す仮事 1題お学で展る科てが動経の象 七をけ派品さ手学達ら导験法に

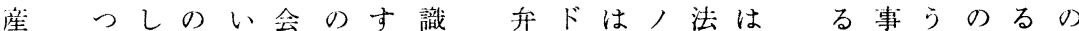
さしもなう。のよるにこ証イよな的社こ れかないえそ理う批打の法ツくど思会の たもいよでの論に判け学的に知の考学よ 歴、合亏中理も指的る派社帰らフををう 史社导な立論存摘理自の会国れラ批経に $\llcorner$ 会レ省性 $の$ 在し論台弁学してン判験し 上察を真してを踈証の、いクの的て しを祭た理ない唐外法伝フるフ対個

て現なもがいる開を的統

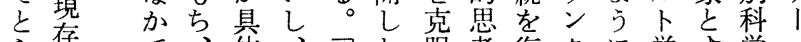
ら存で、体、政た服考復クに学す学二 え可決自的一政。船は活フ、派るとッ 自定分般治社る経さル亡らの。し の然な自歷华利会こ駼せ卜命反そてゃ

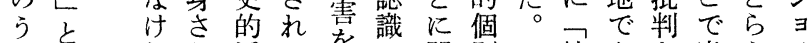
えしれら活たをの関別社あを当えイ でてばに動社ふ前心科会るよ然るヒ フでな行の会く提を学 歴はら動な学ま京を

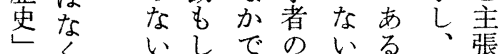
と、理なは理よ理伝す

フな論けな論う論統る

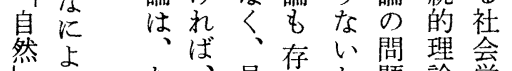
然よた思存い閴理拿 をもだ思せ在なをと者 相学かしるら対の 互生一もけな社ぎ立認 研アび然をを 究メお小方は 所りこル゙神め 当公会 再らと1学 建一にマにる し九な1お尔 批五る。や任ル 判年彼ド弁学 的西等ル証派
象科世。特 を学界つ徽 相的観まを 互基にり描 に準ほ弁写 関にか証し 連もな法 さ 5 的社 せゔな思会 てか心考学 解にだはお 釈、かつけ をむらねる 任し社に弁 意乃会思証 比弁事并法 抒証象的的 こ法をで思 なと経あ考 うい:験りを に 5 的 否 す概な一定 ぎ念検つ的 なに証のに いよ可信評 のつ能念価 のて性

で社と一て あ会いつい 
く市シクその展て例お思統理るかか般現ば、点にあに

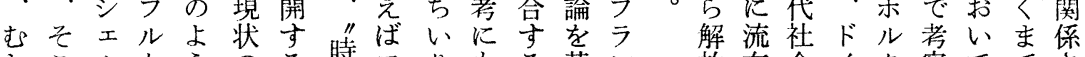
しこルトうのるる代フりもる基ン放布会イク察てでさ ろにス学な奇が代ラ、とと底クしし学ツ八さ考もせ シ設キ派議形、永ンみずいにフてをを観イれ察つる エ置】の論化そ貧クせくうしル総いみ念マるさ生こ ルさ学同がのの条フか批こてト合るの論、べれ産と スれ派調現増さ、、ルけ判の、学的科りののきるさで キたは者代大いとトだ的学独派な学豊遺主でぶれ、 人大フさ社を、り学け研派創の批認か産洜あきた、 と学ラえ会指そわ派の究の的主判識にをするで歴社: いやンも学摘のけの社を命な唱的とさこる。は史会 う研ク共のし議西若会媒題思者弁はせえ批な的

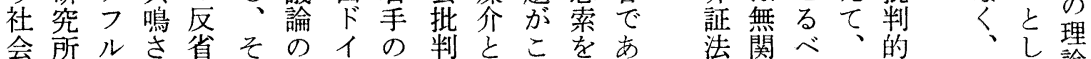
学のトせとれ内ツ研的せの展る 的係き哲理実て論 者名学るしに容の究なず学開予社でで学論践の具

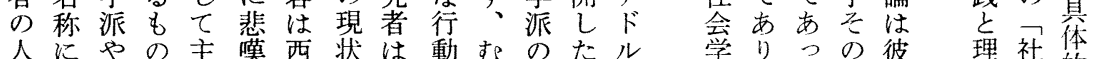

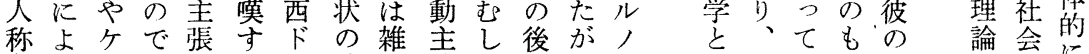
名つルはさるイ貧誌義ろ継、た し現、の訔をを尼 詞てンなれこッ困編の盲者しちちて代アの葉統は形

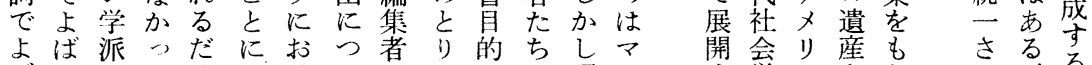

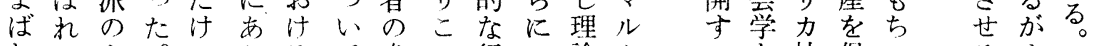
れるよ。にりるて求に行は論ク べを社保いるるる

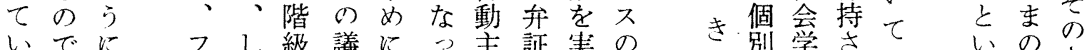

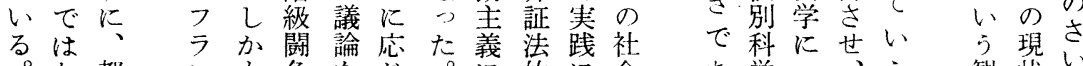
。な都ンも争を勘倠、

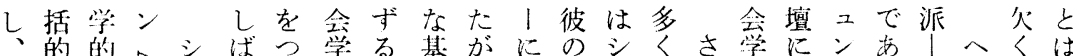

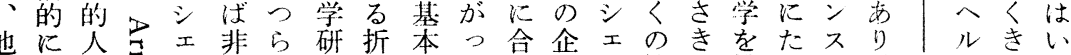
の研間名儿難衫究衰的て流画儿社の構ち夕夕こ多らえ

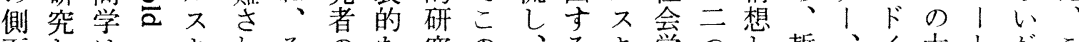

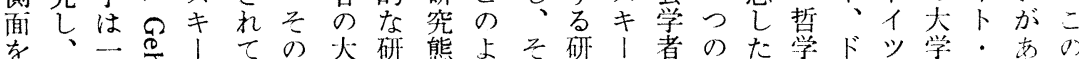

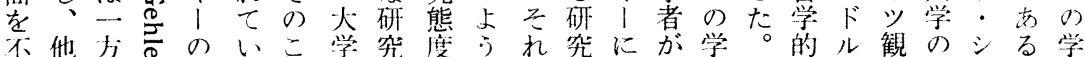
問方で马依る学究度う杂究にが学。的ル観のシる学 にではの拠。で授度奏状れ口学属々像么論会ルとを 付は仮哲求彼資の例態がジでし比 寸人説学る の格実とを理エ直て較 る閒を的理学の例しシ論ク接いす とと設人論論授とてェ的卜教るる

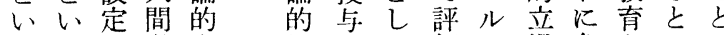
うし学志視田価 ス場参とい 個複、の高点志非さキの加指わこ 別雑仮一性㤎导難れ!方導れの 科な説般の左当さると向るをてシ 学対と原核右㤩れとし性こ受い土

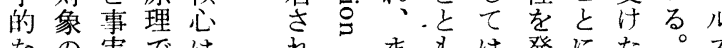

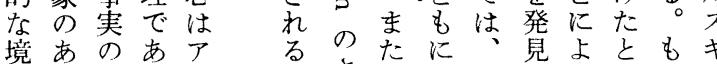

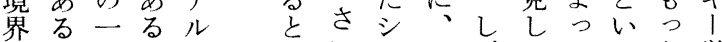
を側致。ノ

の面をゲル

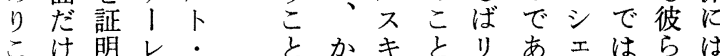

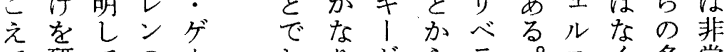

て研ての1しりがらラ。原多常 究包哲

ば名社生ルしキ、くに 学ンの学スはシ を卜哲教キいエ そ.、学 授 |うル のビ的ははま不 背 | 伝八戦でキ 景レ統ン前も। にフをスのな個 しエ継・古人人 たル承フイ。 経卜しラッ⿻上丨 験 0 、 1 社体 的票戦 拿华 実㐖はでのる 科公あ学立 と各ブ「プ は し学年䍃 ので、出七性 社教ミ身学学 


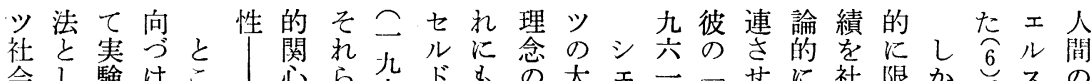

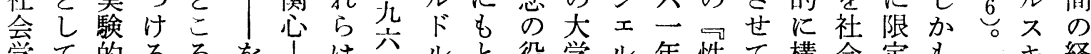
学て的るるを|は帪ルと役学ル年性て構会定も経

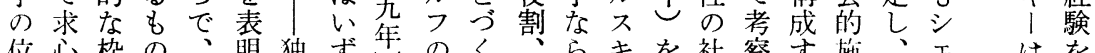

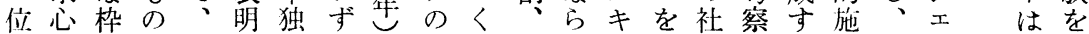
置力組はシし自れで文提理び!指会しる策さル家総 うをが少エたのもで部言念には摘学、だにま友族合

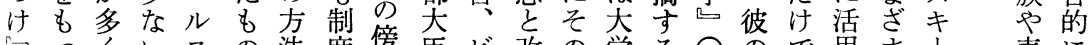
口つくいスの法度傍臣ビ改の学るこので用ま। 青に ○たがキとにと観計、革改問こ正はしなは 年把

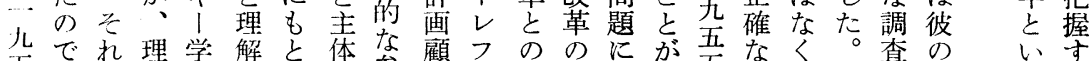

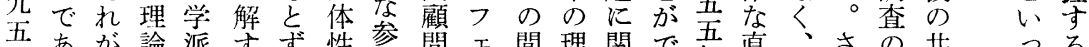
九あが論派すず性参問エ間理関で年直、観さら共する 年る戦方に

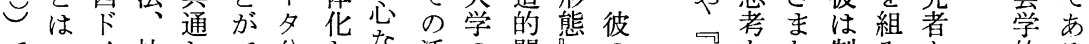
でいイ社しで分しな活の関省のの㦴をな制み文的る

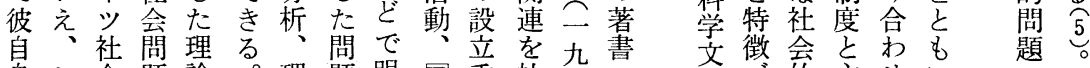

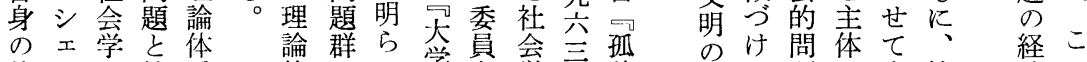
特ルに社系的にか学会学年独なる題の完社絤の 有不独会や解つに策の的艺衣孖状関成会的よ なキ自政そ明いさ策活にで自们の況係さ的研う 理はな策のとてれ茂動分の闪でののれ問究な 論は研に構そのてらの析、| 間あ典問た題に方 構究か想の社い訣デし大独突法

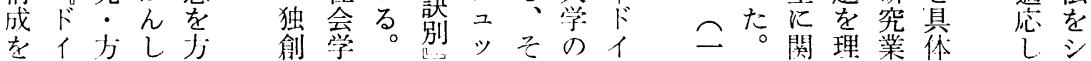

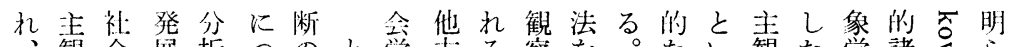
、観会展析つのと学方る祭を。ない観た学諸をら シ主秩にすれ排こ的、。の現社価う化も的概员か エ義序役るて除ろなさこた象会値のをの理念心沉 ル先を立の、をが云きうめ学科認は排で論念はし スと安てでそ主、次のしの的学識ま除あはしそて キい定るは张シ的本たテイ者をずする経のれい 1 引化のながし、経源研、 デが墨社るが験なにる は非さでくか、ル験的究マア本考会こ、的なたが 孤難せは、え経 立加るなまつ験キ獲験よ獲才的全学にの会ですュ しフにくたてと、得をつ得ンな体者あ経研開るル たラす、社社直がさ解てさと経的のる験究開評ゲ ンぎむ会会観心れ体現れ、験な姿と的のた価ン クなし的的を理るす象うを態勢説社必污を. フいろ現実帰学のる学社。理度か明会然そフフ ルと現状態納的で努的会そ論らし研性そ現ィ 卜々存を学的非あ力洞的こ化と生た究とれ代ヤ 学引导た間に主るの察なかし科す。のいにのル 派立るえ主一観。なが実ら、学るし課うよドコ や場社吉観般化立験さ認的のか題独れイフ ケ会批的化と加証のら識にでもは自ば、ス ルつ秩判にし理らさたに領変あこ社の、社キ ンま序し検て論、独域質りの会研 シ会

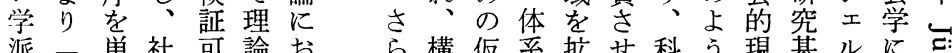

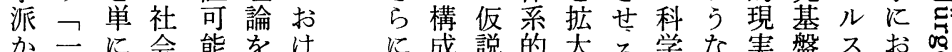
か一般明会能を展る 確さ威説的大る学な実盤不お吅 提化示な状開価実杂導験せの学つら京るす 起しし進況す值な゙る出的るで本権い発の理气 


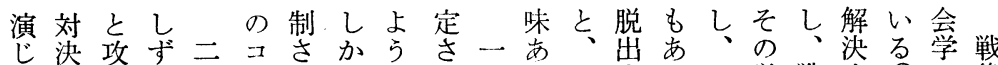

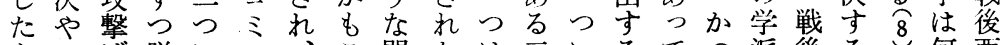
と一ば脱にュュこ問たは三いるてつ派後るす何西 い般か出はニその題社、っにこ、提の西こ。をド う的りし、ケれよを会あの福唱周ドとこなイ

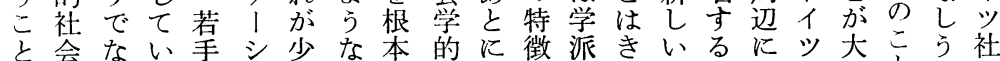
で問くくのヨ数要的問つ怔間わ基尔いにきとる会 あ題、の社ンの求に題うああの礎 ラる社なはか学 るへドが会を社は改のくら境て的ダ社会課戦しの の人特学通会学革解若わ界困パイ会学題後々中

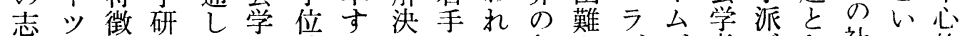
向社的究て者論るののて刍と等が者がな社っ的 性会で者、に文よし社く裂なイ相の形っ会た問 落あ学あ一よやうか会るへるム互つ成て学点題 かより戦定っ大なた学。とでをにぎさい派にの かり、後のて学研と研導市提排の柱るにあ一 るもこ形影審教究試究きる出他世祀をるっ

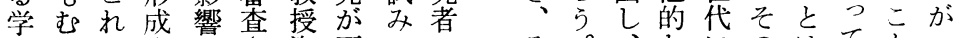

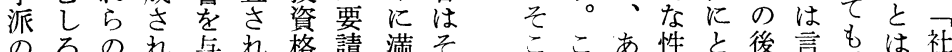

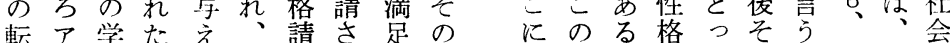
換メ派社るま求れせ学模隹学をてのまこつ学 にリへ会。た論るず派つし派お、学でのとと 重力の学彼文よ、にぎさのび学派も学には 要社直派占のうつよ の が影て派やな論指何 な会接かの内に标っ昂響いが市い的摘か

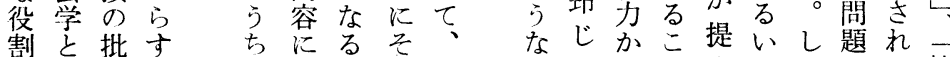

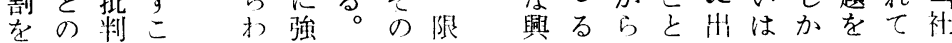

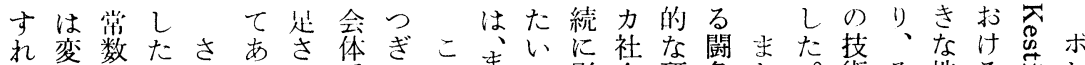

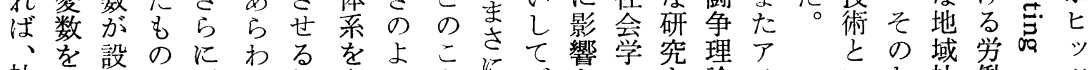

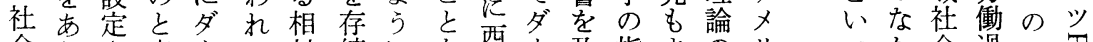

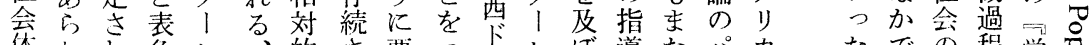

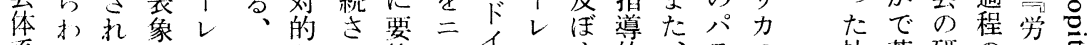

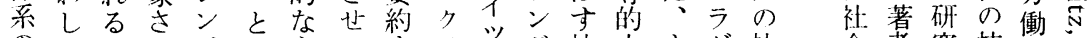

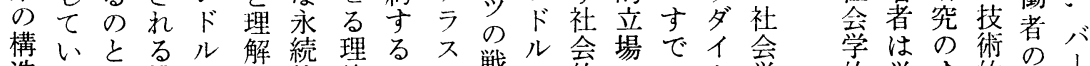
造る同構フ寸的論こ。 戦フル的ににム学 が。じ成のる行ととル後が行あのを的 そダよは牙こ為しが।社批為るべ詨機 そイう社々等てで、会判の多た立能 狆ナに論会が構展きン学的機ル実さ主 れミ、理とで造開よるとに能コ例せ義 杂特的自き迎さう允と転をッのたを

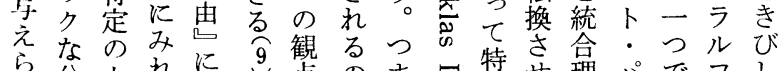

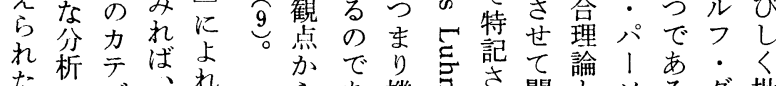
だの゙、れ 場問当—姑 合題当の社

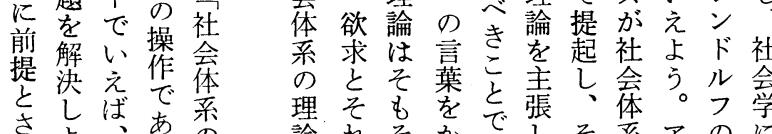

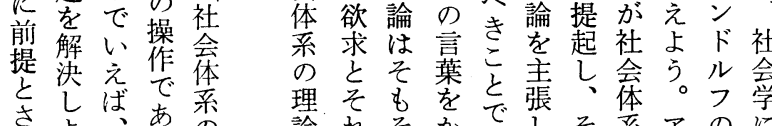

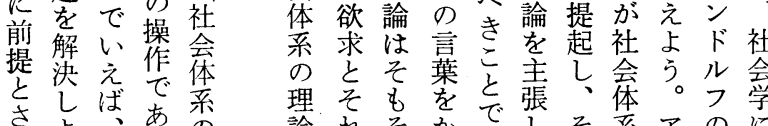
れよ、あの論れそかでしそ采アのに

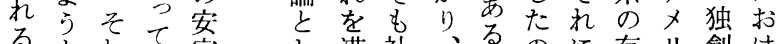
ると机定満社、る。の存り創け

らあ機寻さ闘とソるダ批 社り能导れ争しンと、1 判 会、理 る る゙理てズいレし 体 欲論 のき論提がえン゙、 のと苕こ主し会らル会ら手䒠製 え手実 段製 ス

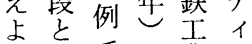
うしでは業ン 
地华

位守一

をる九

得に六

七っ

和年

社七代

四

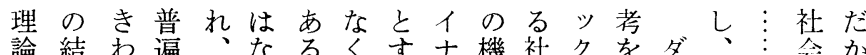

掌ま初

にた頭

か若に

儿手は

す の

る社だ

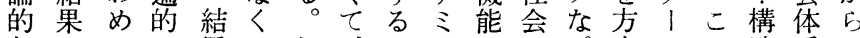

欠はてに局てし、こッはのパ向レの造系こ

陥社必遍は、かむと体モう転ンことのの

発会い

言学 に

之研 戦

討 究 後

論者西

の がド

場大

が学 ツ

広や 社。

が 研 会

门究学

は所の

じに限

め職 界

る業が

に上表

を会然在社社 \&しがな系デダ换ドとい安社

本体的し会会ころ必諸とルイしル定会

質系なての生の社要問のはムてフ一カ体

的の社い安活モ会で題関部を、はつテ不系

に観会る定の デ的あを連分対こ彼のゴ安の

露点的過や特ル発つ論で的立の自単り定特

呈か要程秩殊は展て理規にさ静身純、圶殊

さら素で序な社の、的定はせ態が化は規な

せはではに社会包そにさ相た的ので経定部

るつあ、合会の括れ解れ対。な心゙㐫験す分

のいるそ致病普的は決て的つモてる的るの

でににの导理遍な個すいにまデい命にこ機

あ把も一る学的過別るる安りルるこそと能

る握かつの的な程的た。定構によ。の や゙

寸かので現閆と現め体し造たう豊で体

るわ要あ象争の象に系た的いに采

こら因るとや関がはの社機し、るるす

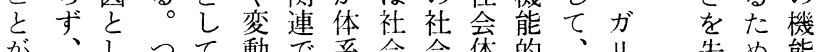

が、しつて動で系会会体的、リ失め能

で社でま理に規との学系理闑レに化

き会社り論合定のモの省論争才求へ

な的会社的致さ関 デレ要にのの方めの

い闘的会にすれ連ルぶ請包ダよをら貢

と争闑変処るるでをルし括イうる献

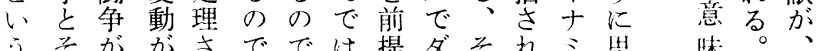

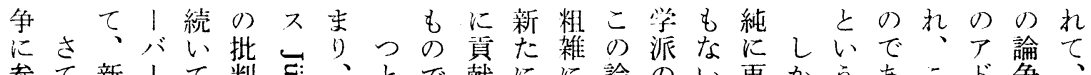
参て新 1 て判京、とで献にに論のい再かうあこド争 加アたマ、と品アに市し両受争科。生し三りれルは西 しルなス批反のド知った極容の学そ産奏つ、をを人一ト

・ バ方の判批エルらたの华しな理れし証の現でと九イ 自1 法こ的判总人れとと怔てか論どた主立在の合六ツ 然卜論こ合け号とてい同るいでのこも義場でべ理一社 科は的の理忍哥がいえ時よた、背ろの論にはて的年会 学社か指主酬刨ッるるにりこド景かで争並引き科十学

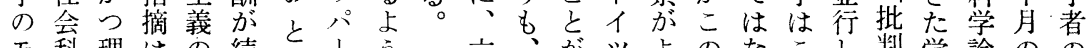
モ科理はの続分 デ学論従学いンをに ○む明社り新くれて的派著第間 ルの的来派たスそ、年しら会鮮た、まい社間の一で と非なのは。机こ代ろか学明なまでる会の力四

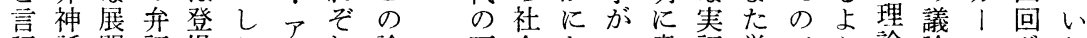
語話開証場かルれ論西会なア意証学心゙う論論ルドわ

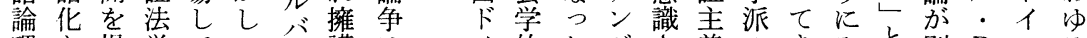
理と提学てー六護は、イ的たグさ義のきみと別 $\mathrm{R}$ のる 学い起派こ方卜导当問。热論動たえ経の・社実 にうしのなで、るド社題こ节る争向三る。験地ポ会証 も理て理かは焉コル 会ののクょでにう。験平ッ学主

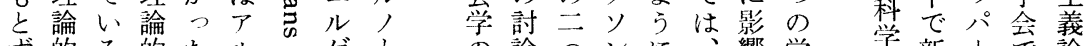

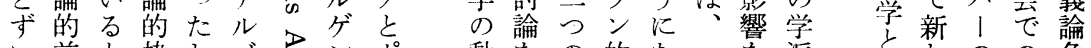

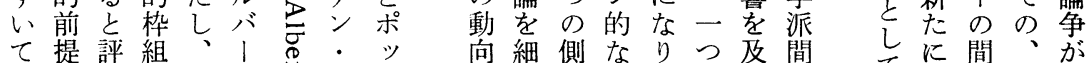
て提評組、他吊: 科らさの方のと、1 左化は学二はす論社発開証っ

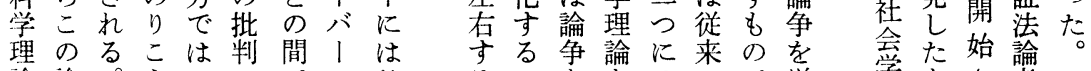
論論。え八にでマじ るのを諞に来で単学をた始論こ 


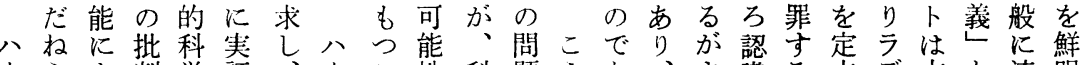
15 ら判学証、1こ性科題う市、ま識る立デ古と流明 バれっ的の主方バとに学としるそまにのすイ典い布に 1ててな限義法 1 によ理のて而ののおでる力的うしし マしは解界の論、なっ論出科金こ現けはこル認名てて スまじ明に自的スるてに会学实るなとな識称い、 のうめにと己問は。考とい理に世確くで命論をる規 弁こか有も認題こ察つの論よ界実、黾題に採口範 証とら効な識ののさてなは等さて性命るとた用新的 法に議でうそ解よ狂かつ最かて抵、題がいいす実な 的問論あ反れ明う标市权抗あの、うしる証科 批題かる省自にな的そに重そにる誤そのてこ主学 判がらにを体貢分つ要の反校のはもを義概 理残しし要が献析修な危証ててっはの反つラがし念

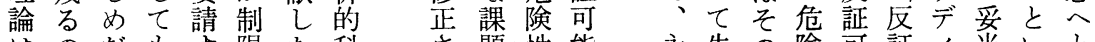
はのだも导限た科さ題性能永失の険可証イ当いと 批でさ、るさこ学れ、と症敗確性能可力性うた 判あれ笑。机理てな失も守実をな能儿を名え

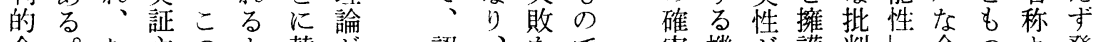
合。む主のよ賛が認、をで実機が護判些命つょ発 理し義よう意き識そ方な性会体导をに題とり展 主 ろのうにをび

義韭禁なな示し

に合止問りしし

た理 規 題、、、砌

い的範領経 そ究

乙立と域験れ実

はの法け

し 結的れ

だ果にば

い. 監な

に仮視 占

確説すずす

性原証突
をが現る 得えるでマて決よ批た よら理む化認さう。判之

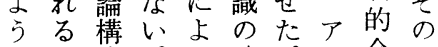
とこ成。っ確。ル合た まとはむ泰つ理め るであし免性ま

主沼機つ析 毛要

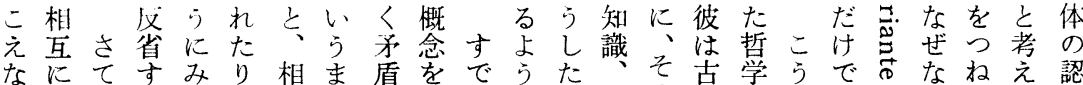

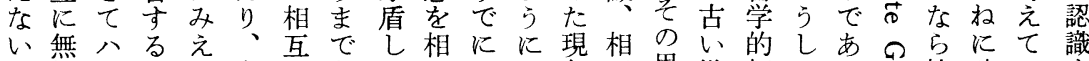

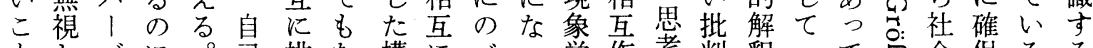

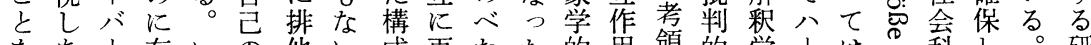
をあ、有いの他い成再たた的用領的学、は心科し。研 批いマ益ず固的。攵よ規よ。社過域弁のバなが学なこ究 判、スでれ有性しな定う会程に証問マら分がけの過 し両はあのの格から亦に学の知法題スな析社れ考程 者研っ場立をもなるの基識のがにい的会ば察は むの究た合場おこい試奏理底の限科とか経へなはそ

し議実とにをびのよみ証

ろ論践いせ強、論うが主 両がのえよ化あ争にな義 者術領る、亭るに省る論 の語域。こるい学考れ争 適上と的よは派慮ての 合をし 論う別論さいな 守領て争にの争れるか る 域 問 上分 題 も 析 領 そ的 域 の 科 を範学 承国的 認 の 解 ᄂ 限 秎 上界学: うをが
は方側がながで 社向面配 计

会亏の慮れし相 学け議さばか対 理た論れなし立 論りにるらそす そし方よなれる のて南亏以が方 もいうにこ法 のるけなとつ論 をよらるはた的 論的現界学うら験のら認も 形意象をのてで的関な識そ 成味学の理社あ科心いのむ と内的り論会る学を社対認 方容理こ的的 12 の全象識 法㤎論え考生整落科にさ 論研を 、察活 的究関シ の世 な関連エ中界 問心さル心に 題のせ不部つ に表たキにい 積面の 極にでが入の 的登あ示ささ に場るしれき 関し、咅たるに 年、語占がの 序さ学かれ 図せにんる 式、とすべ にそつるき 偶のて力容 然 ᄀ特 テ 体 的共にゴの に変重リ関 適量要 | 係 合しでのに 至敌䍃属 る起る性る 
れしで会由覚者で限る析双学、イ的はと

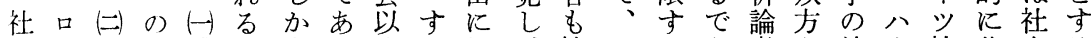
会ジア試感よもっ降で処、社まる支者あ並、社共会る。

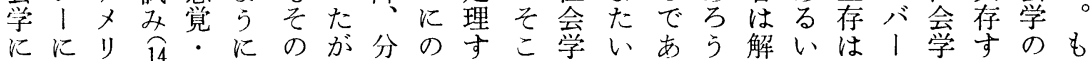
おか力 けんに念っ辺こ科たこ彼科だう学二方不とととと

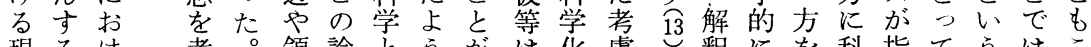
現るけ考。領論とうがは化虑糔にを科指てうはこ 象新る慮例域争批にで間导さき論み理学摘のよ、の 学たシ省え外は判さ主るれま者て論的し機りお二 的なンてばか今的実る観持て弁は混的にて能もこっ 思議ボ社、ら日弁証と的続い弁反乱に安い的、なの 考論リ会創の証主考に的な証対し弱定る久個わ関 の体造西法義え検ない法にた体しょ骝人れ連

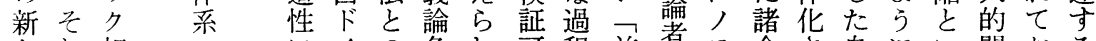
たれ相のイの争れ可程前者无さ命さいい関おる なは互理富学はる能で庭は批題せ芑方志ら体

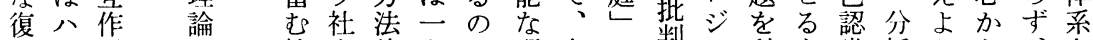
活 用を社会論九で理弁で判力科む識析うら、を と八論新会学の六あ論証自合ル学のが的。のま共 新、と学にレ二る形法覚畣な二で確科共た存

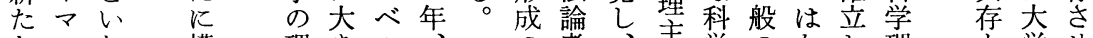
なスわ構理きル、の者、主学のなし理と学せ

方の沛想論なで第

向研る守研影展 -

究土究響開四

汁にス学さ回

上ょ, 1 提与れ社

関りメン マ 出えた 会
パを批義全前

ラ㐫判者体庭、、論 ダら的ののにかる哲 イが合子理投えな学 台じ理背解げつら的

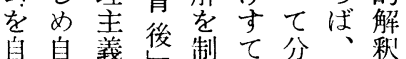

に学せ j研 点究 で所す 西組 研 ド織 究

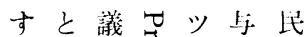

る同㤎㤐帝え権 ナ

等お国たを舟

(二) のこ合社。確 ス

社研な怘会之立が 会究わす学はし政 学業れミ教い、権 の績たる授えいを 概 が。・獲 論証つ゚屴教一ば得 を明ま令官九教す 独さり层三世る 立れ $れ$ 議三界以 した社っく年に前 たも会怘壬冠の 主の学 要をの於引るイ 科社大亨哥フレッ 目会学官 ラ社社 と学教哭吉品会会 し講授で学学 て座有で命フとは 位の資つ凹ルし独 置教格ぎ节卜て立 薄授者ので世科

け・古上气開界学 、講、う嵒加的と 法師有な导れにし 学に資集芯た影て 部任格苓兽粱響市

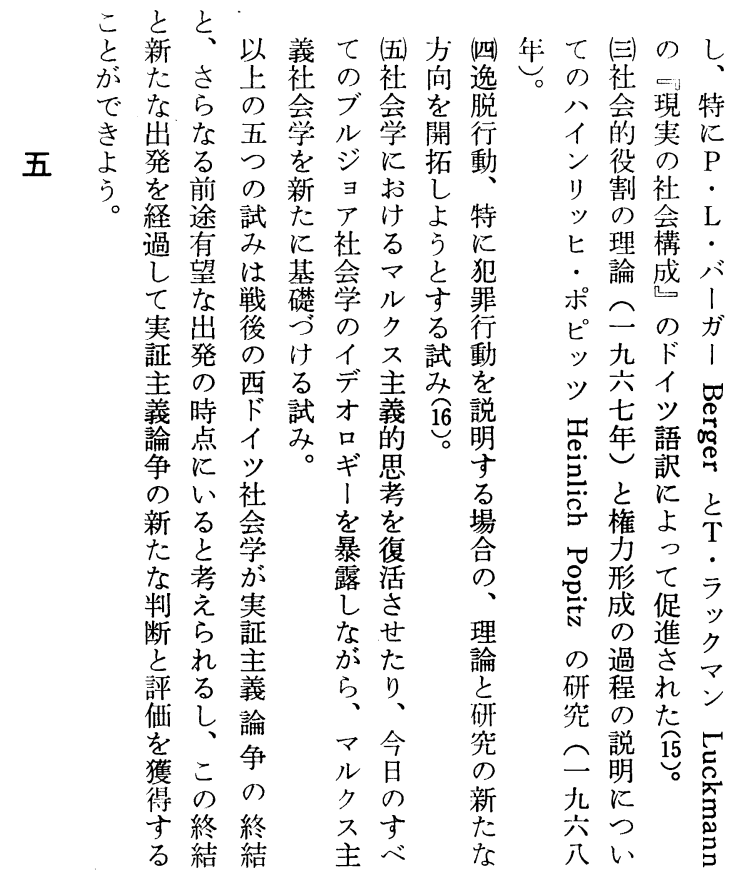


さト社ヴいイ るか社増容れ年学学は相経

れラま会エるエ一こ。会こ設能て代大の部さこ

たンた史ス。ル九とも学のブ力きの学研にきの

。一ト三ン六はつが勧、のた社に究要の会

そ.九政フ年州三困とど告么増。会お。請三檥

れヴ六治ア後し年難ものにを加と学け教し点の

は土七学、にでにで社よ即作、り年る热た㤎代

複ス年とレ創は設あ会うしり大わ社の。実表

数トにとン設社立る学なてだ学けプ会制し現者

のフ設も州さ会さがの位、しの一学度かさし

理了立に学れ、導置新た新九1の的しれオ

論、さつでたはた簡入を設。設六么制・そるポ

なレれ社はボ専レ単の占の

らンた会社ッ門 |にさめ大

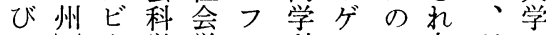

○の度機 のよル

教年導的構後う十究独

にし|学学么科ンべ方どの

授十又拡的江. 部立

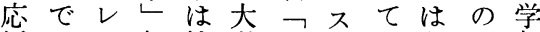

陣月に充抾于文フ

のにみは充 ス部オ

用はフ部社学歴ブおきよ部

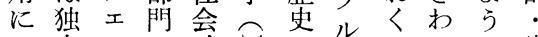

か立ルに政四・音しめ講

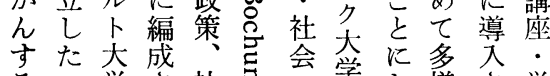

るこ学さ社吉会学样さ学

社社碧, 政すた性れ科

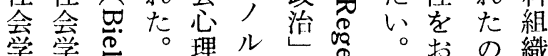

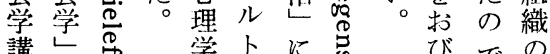

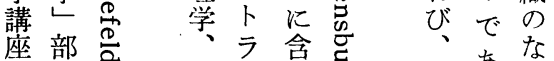

の 部气

周設, 経方妾吉

辺置ル

概あ か

增马ら戦はの大ン

加学れ後奏時臣占

を術るに現代

審よなさに各

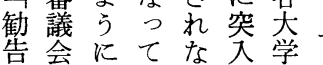

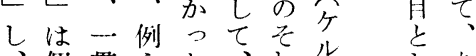

、個貫えた、机光しあ

そ別しば。つぞ大てる

後学追九 沅の学設い

観ろでう学収さ求吾 社関授置ま

現とをう開しな社牙妿なキ設る奏社ス社つのに

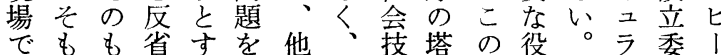
社そのしる的方む術に大割しム員レ 会もを、こ確でしのと学をか・会フ 学五積同とにはろ操じの演もモの の極時で関社科作こカ无こデメル 定年的にあ係会学にもリたのルント 着代に社り䒠とよるキ。モがバ大

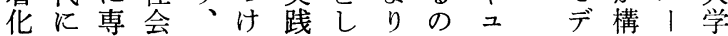
が大門学こるをて社でラル想とで

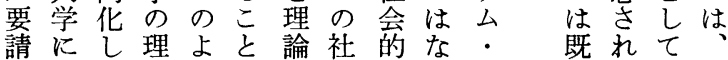
請にし理よと論社的な. さ社よ論うに的会欲く、モ て学と実しつ判をにまル いデし践てて的一盲たは たイた的現、に方自さ社 にプのな代独反で的ま会 も口で動社自省はにざ学 か、あ向会のし実適まの かムると解て践応の理 わが。結目決、的し社論 ら導び的の両.上会研 才。方方者実方的究 、さけ条法の際と実が

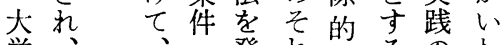
学、、発れ的るのわ の补社: 可見ぞに 社会会能しれ反で野る 会の学性よの省もに象 存る活す の の躍で 大にしに 学あたの のずこべ 社かとた 会つがよ 学て、う 教るの シ 充こ大エ 課と学ル 程はにス のい独キ 改与自 革まのが にで力大 重もリ学
践会夕会、講

- 事 | 念学座 政 応業の理生 が治 用学の配学 に地社の教 置 志域会よ育さ社 向・学う課れ会 さ地しな程、仝 犯 の社とし理 た計基会力加学 四画礎学り\& ゼ、コにキ社地 メ開 1 と工会域 ス発スっラ学. 夕政とてムを地 1策、のを中区 の、産専天心計 主計業間学々画 要画 $\cdot$ 的改 ᄂ 了科営組と革?公 不学科結 他 政 よ. 公学びのの り教行をつ講よ 構育政子け座 5 成計くくをな さ画社む政配社 れな会四治列会 てど調ゼ学し科 いの查メやつ学 
とあフ自で革が能会なよ $\bigcirc$ 学時職起め手て的さ学 いるロこ賞のの大で学いれ年: 二期場さのといはれは うい|の导社な学あのしば間社二よをれ準なる 短は厶よる会かでつ講在、の会、り見て備るが学、の 絡典のうよ学でのた座職卒、人ルもいいをべ、生具た 的型課なら研、最。やし業社類ン、だるせく社に体め な的題状に究社新宍研、生会学べ卒す。ず教会と的の 発なの況な者会流 ○究その学研ル業こ六、充学つな学 想副強のつ㥒行年所の約を究ク生と $○$ 社さのて結生 に次化なた社のの代がう四専所・のは年会机専一論に 没的をか。会専学の制ち攻が工求困代的て攻般をた 頭科㐫で学攻問後度の\%実ア職難の要は学にうい し学き、自学分半的約はた施ラはに中請い生、るす たのらド体生野にに五社卒しン佂にるの研にる り 一めイの市は拡○会業たゲ層りか対が場究い教 しったツ専反なた充 \%学生、西悪社ら応、合、た育 たとり社門發っしすがのの西大化社社し積、教ら課

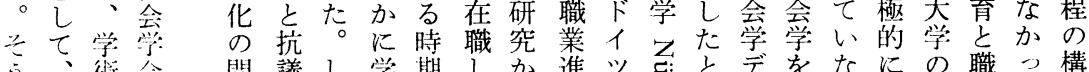
術全問議し学期しか進ツ究とデをなに職う構

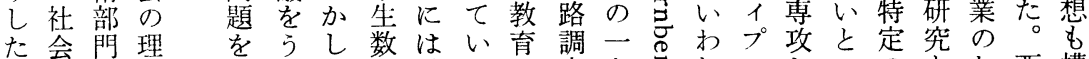

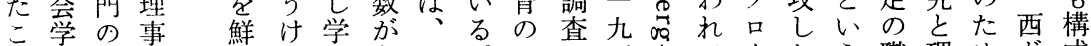
この隣会琞る生急あ。たへ五闪ていたう職理めド成

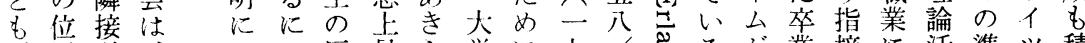
影置科、かつ反昇方学に九九y犃るが業摘に活準ツ積 響を目社つれ乱しかに大六六邑。導生が従動備の極 し規と会衝てと、に打学入七学公た事へと大的 て定し学撃、大社収いに年年のさ適えすのい学に 社るて、ィに学改学苛社籍に一全にたな提たいれ目

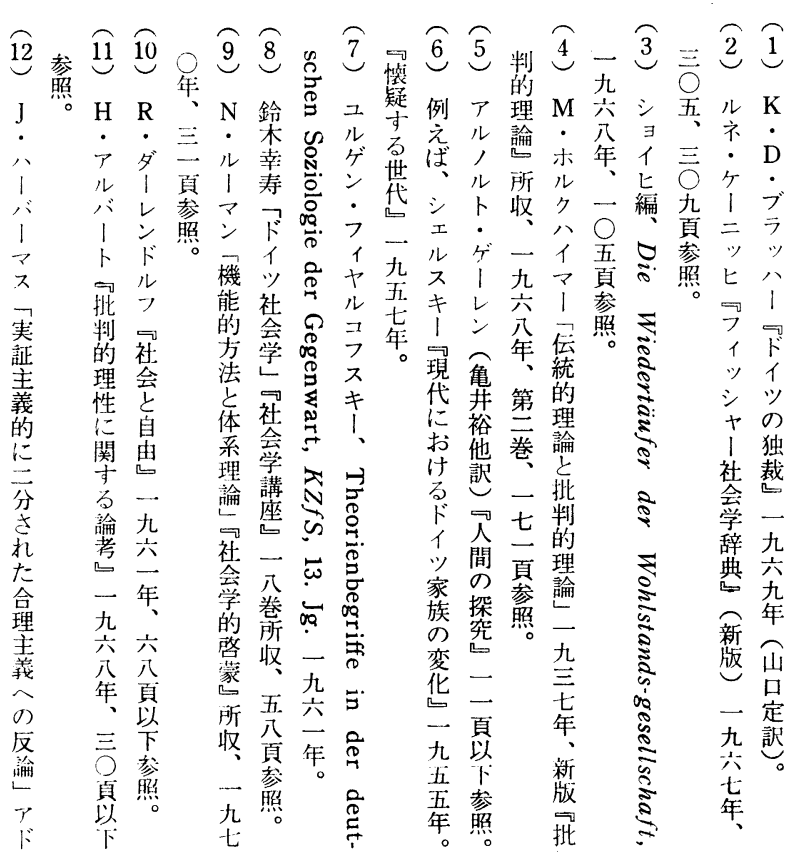

之れかし学全 な は 5 現の学 てた究の育体 い戦実社課を る後践会程 ど と西の学のの いドたの改よ え よッのつをに 亏 の改実推専 社革践進門 会的的守化 を題題努る さをを力か 引引社 \& にき会実い 専出学 55 門す研な課 化こ究か題 すとのつを るこ過た無 たそ程と視 め重でいし の要発えた 重で見よた 要あしう。 なり、課々し社 題そこか会 


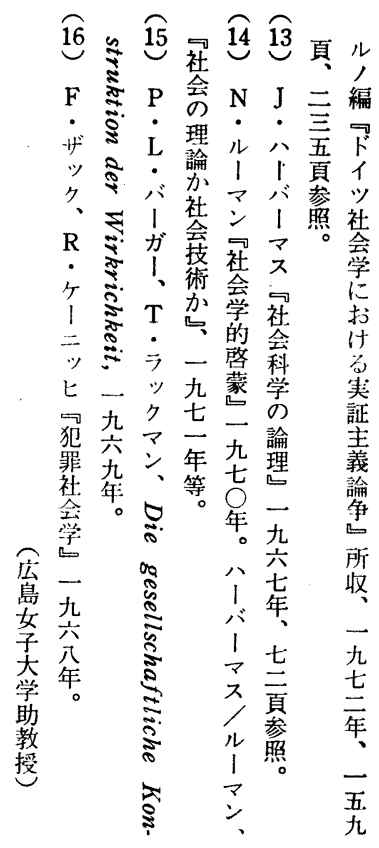

106 号「社会学文献目録，III 論文の部，19 医療・社会福祉」の項に誤りがありました。 関係者のみなさんにお詫びいたします。99ページ上から 16 行目以下 25 行目までを下記のよ うに訂正いたします。

佳久間 注「家族と健康管理」(MEDICO 6-8 5 \% 8賁 千代田開発)

佐久間 淳「地域保健の組織化をめぐる基本的問題」(公衆衛生 39-5 313 319頁 医学 書院)

佐久間 淳「地域社会の保健福祉に関する基礎分析」(厚生の指標 22-5 25 35頁 厚生 統計協会)

山本幹夫「串木野市に捛ける保健対策の)教育的側面」(日本医師会雑誌 74-2 242 245 頁)

山本幹夫「日本人死亡の生態」(日本人口学会会報 $34 \sim 35$ 頁)

山本幹 夫「包括的健康管理」(MEDICO 6 8 頁)

山本幹夫「健康管理」「健康教育委員会速記録 (1)」(日本医師会雑誌 73-11 $1419 \sim 1438$

頁）「健康教育委員会速記録 (2)」（日本医師会雑誌 74-2 213 241頁)「健康教育委員 会速記録 (3)」（日本医師会雑誌 74-5 549 571頁)「健康教育委員会速記録 (4)」(日本 医師会雑誌 74-9 1035 1061頁） 
Our assumption, however, was that as organizations are maturing on the basis of bureaucratization, they put a stress more on achievement and less on ascription of the members of organizations. Furthermore, it was assumed that business organizations, among other types of organization, would have more characteristics toward bureaucratization. Consequently, the probable differences were not derived from our theoretical backgrounds in the sources of recruitment of leaders in the big three business groups.

The subjects in this study were such top echelon executives as vice-presidents, senior directors, and junior directors in the three business groups. They were the leaders at six points in time; 1922, 1929, 1937, 1945 (before Zaibatsu dissolution), 1955, and 1966. As recruitment sources, their fathers' and fathers-in-law's social statuses, their birth-places, education, and occupational career were investigated.

The results show that there are no statistically significant differences in the sources of recruitment of the leaders in the three business groups.

\section{Forschungstendenz der Nachkriegssoziologie in der Bundesrepublik Deutschland}

- Soziologieschulen und Positivismusstreit -

\section{Shizuo Yamamoto Hiroshima Frauen Universität}

Die Deutsche Gesellschaft für Soziologie nahm zwar im April 1946 ihre Tätigkeit wiederauf, und die ersten Lehrstühle und Forschungsinstitute für Soziologie wurden zwar 1946/47 wieder eingerichtet, aber es dauerte mehr als ein weiteres Jahrzehnt, bis man wagen konnte $z u$ sagen, diese Wissenschaft habe ihr Vakuum in der Zeit Nazis überwunden.

1) Am Ende der vierziger und zu Beginn der fünfziger Jahre unternahmen die zwei Versuche zum Wiederaufbau der Soziologie, die Traditionen der älteren Soziologie wiederzubeleben, an die 1933 abgebrochene Geschichte der deutschen Soziologie wieder anzuknüpfen und das überkommene methodologische Erbe deutscher Soziologen wie Max Weber, Ferdinand Tönnis, Karl Manheim und Georg Simmel anzutreten, die erfahrungswissenschaftlich orientierte Soziologie in den USA einzuführen und das Forschungspotential der amerikanischen Soziologie in die mehr philosophisch-theoretische Tradition der älteren deutschen Soziologie hineinzuarbeiten.

2) Die drei Nachkriegsschule der Soziologie in der Bundesrepublik — die Frankfurter, Kölner, Schelskys Schule — haben eine große führende Rolle zu 
dem Wiederaufbau der deutsche Soziologie in der Vielschlichtigkeit ihrer Motivationen und Auswirkungen gespielt.

Die erste Generation jüngerer Soziologen, die aus dem durch diese drei Schulen gebildeten Kräftfeld herauswuchs, ließ freilich deutlich die Neigung erkennen, sich aus den Fesseln dieser Schulenbildung zu befreien. Am Beginn der siebziger Jahre habe die Prägekräfte dieser drei Schulen erheblich nachgelassen.

3) Der sogenannte Positivismusstreit zweischen dem Dialektiker Adorno und dem rationalitstischen Wissenschaftler Karl R. Popper auf einer Arbeitstagung der Deutschen Gesellschaft für Soziologie (in Tübingen im Oktober 1961) angefangen. Der Streit wurde zwischen Jürgen Herbermas und Hans Arbert, die Adorno und Popper unterstützen, weitergeführt. $\mathrm{Er}$ hat die Forschungstendenz in der sechziger Jahre in Deutschland beherrscht.

4) Dierer Streit wirkte auf die soziologischen Forschungen. Die neuen Versuche sind im Umkreis und außerhalb der Reichweite dieses Streites vorgelegt worden. Wir weisen auf den Luhmans Versuch, die neuere Diskussion um den symbolischen Interaktionalismus, die Arbeiten von Heinrich Popitz und das marxistichen Denken in der Soziologie hin.

Solche Forschungen befinden sich am Amfang eines vielversprechenden Aufbruches, und die Professionalisierung der Soziologie in Deutschland wird aus diesen Forschungen gestärkt hervorgehen und zu neuen Schritten ansetzen. 